\title{
A cooperação recíproca entre os governos e as diversas formas de incentivo às transações internacionais
}

Truman Bidwell, advogado militante em Nova lorque na área de direito internacional.
Quanto ao papel do advogado, julga-se que este profissional pode ajudar os homens de negócio porque é talvez mais solicitado para oferecer soluções objetivas a questões difíceis. É importante nas negociações externas conhecer antes de tudo o mercado e onde o produto pode enquadrar-se nesse mercado, o que certamente implica conhecimento de legislação estrangeira. Mas a primeira coisa, naturalmente, é conhecer o clima, as práticas e as possibilidades comerciais do país com o qual se vai negociar, porque, afinal, é o comerciante que faz o projeto; o resto é mera assistência.

A par disso, é também extremamente importante conhecer o apoio disponível, seja em termos advocatícios, seja principalmente em termos de financiamento. Não somente existem as novas fontes de financiamento do Oriente Médio, porém muitas outras, particularmente privadas, nos Estados Unidos, na Europa e alhures. o contrato de arrendamento (leasing ), que estaria sendo empregado para contornar a incidência da lei islamítica, é instituição familiar ao meio norte-americano e europeu, cada vez mais proveitosamente utilizada nas transações internacionais de financiamento de fábrica ou de navios, aquisição de aeronaves e outros bens de capital. O leasing provê meios de o usuário do equipamento receber $100 \%$ de financiamento, porque o equipamento é comprado por alguém mais e arrendado ao usuário, que, assim, logra taxa muito mais baixa do que a obtida por outro modo no mercado financeiro. Esquema imaginativo é quando o leasing é realizado em dois países com o bem usado em um terceiro, modalidade conhecida como double-dip, proporciona redução de juros da ordem de $6 \%$. Vê-se, pois, como a combinação de financiamento local com créditos de exportação e importação e outros subsídios pode redundar em taxas atrativas para os usuários nos países com os quais se pensa negociar.

Finalmente, em bases governamentais, tornase importante, especialmente nos países do Terceiro Mundo, a cooperação recíproca entre os governos, a fim de poderem auxiliar os negociantes em suas transações externas. Recente exemplo dessa cooperação é o pacto entre os Estados Unidos e a China, permitindo aos negociantes a venda direta aos respectivos governos, os quais, então, se encarregam dos demais problemas legais da transação. Esta e outras formas de apoio estão assumindo crescente importância nas negociações internacionais, à medida que o mundo se torna cada vez menor e nós todos temos de cooperar para a melhoria da situação financeira geral.

\section{Simplificação dos mecanismos de financiamento do comércio exterior}

José Fernandes Luna, funcionário do Banco do Brasil, presidente do Banco Brasileiro-Iraquiano, sediado no Rio de Janeiro
José Fernandes Luna

cíprocas - exigem dos advogados e departamentos jurídicos de todos os bancos, não só das agências financeiras internacionais, dos bancos de co- to do comércio mundial - em outras palavras, os mecanismos de financiamento de exportações re- 